DOI https://doi.org/10.30525/978-9934-26-038-4-23

\title{
ОЦІНЮВАННЯ ЕФЕКТИВНОСТІ НЕМЕДИКАМЕНТОЗНОЇ ФУНКЦІОНАЛЬНОЇ РЕАБІЛІТАЦІЇ НА ЯКІСТЬ ЖИТТЯ ЖІНОК ПІСЛЯ АБДОМІНАЛЬНОГО РОДОРОЗРІШЕННЯ
}

\author{
Куравська Ю. С. \\ аспірант кафедри фізичної терапії, ерготерапії \\ Прикарпатський національний університет імені Василя Стефаника \\ м. Івано-Франківськ, Украӥна \\ Чурпій I. К. \\ доктор медичних наук, професор, \\ завідувач кафедри фізичної терапї̈, ерготерапї з курсом фізичного \\ виховання \\ Івано-Франківський начіональний медичний університет \\ м. Івано-Франківськ, Украӥна
}

\section{Янів О. В.}

викладач кафедри фізичної терапї̈, ерготерапії з курсом фізичного

виховання

Івано-Франківський начіональний медичний університет м. Івано-Франківськ, Украӥна

Вступ. Період, коли тіло матері після народження дитини переходить у фазу відновлення, відомий як постнатальний або післяпологовий період. Він починається після народження плода й найінтенсивніше відбувається продовж перших 6-8 тижнів [1, с. 1]. Крім прийнятого поділу на ранній (до 24 год) та пізній (до 6-8 тижня) післяпологові періоди [4, с. 22-23], потрібно враховувати, що фізіологічні зміни в організмі жінки тривають набагато довше. Це обумовлює необхідність пошуку нових критеріїв для оцінки стану здоров'я породіль, які б адекватно відображали стан їх фізичного, психологічного та соціального функціонування у післяпологовому періоді після різних методів родорозрішення $[2$, с. $5851 ; 3,456]$. Таким критерієм є оцінка рівня якості життя (ЯЖ) - індивідуального ставлення свого положення у житті суспільства, у контексті культури і систем цінностей цього суспільства, його співпадіння з індивідуальними цілями, планами, можливостями.

Мета дослідження: визначення впливу розробленої програми немедикаментозної реабілітації за участю засобів фізичної терапії (ФТ) на 
динаміку якості життя жінок після абдомінального родорозрішення (кесарів розтин (КР)) у післяпологовому періоді

Матеріал і методи дослідження. Проведена порівняльна оцінка компонентів ЯЖ у 112 жінок після пологів. Групу порівняння (ГП) склали 47 жінок, у яких пологи відбулись природнім шляхом (ПР). Основну групу склали 65 жінок, родорозрішених абдомінальним шляхом. Вони були поділені на дві підгрупи згідно згоди щодо виконання рекомендацій в рамках розробленої програми фізичної терапії. Основну групу 1 (ОГ1) склали 32 жінки, які не виявили бажання виконувати запропоновану програму фізичної терапії; їм були надані загальні рекомендації по самодогляду у післяпологовому періоді після КР (гігієна, обмеження рухового режиму внаслідок наявності післяопераційного рубця, тощо). Основну групу 2 (ОГ2) склали 33 жінки, які проходили післяпологову реабілітацію, ефективність якої представлена у даному дослідженні. Вона тривала 12 місяців, впродовж якихзастосовувались наступні засоби: кінезітерапія, бандаж черевної стінки (на ранніх стадіях), кінезіологічне тейпування,масаж живота (для профілактики злукового процесу навколо післяопераційного шва) та загальний; оздоровче харчування, психологічна релаксація, освіта жінок.

У процесі дослідження використаний опитувальник ЯЖ «Medical outcomes study short form» (SF-36). Опитування жінок проводили у ранньому післяпологовому періоді (до 24 годин після пологів); у пізньому післяпологовому періоді (6-8 тижнів після пологів); 6 місяців після пологів; 12 місяців після пологів

Результати дослідження. Аналіз динаміки результатів шкали фізичного функціонування Physical Functioning у ранньому після пологовому періоді в обох групах жінок був низьким, але у жінок після КР цей рівень був достовірно гіршим $(\mathrm{p}<0,05)$, ніж при ПР. При ПР фізичне функціонування покращувалось лінійно, досягаючи максимальних показників через рік спостереження.

До моменту повторного обстеження у пізньому післяпологовому періоді у жінок ОГ2 вже виявились переваги розробленої програми ФТ: вони досягли за фізичним функціонування рівня жінокГП та повторювали цю тенденцію впродовж всіх опитувань. В той же час жінки ОГ1, хоча теж продемонстрували покращення свого стану впродовж року, темп якого був значно повільніше,результати проміжних та кінцевого досліджень - статистично значуще гіршими, ніж ГП та ОГ2 (p<0,05).

Розподіл результатів субшкали Role-Physical у жінок, як перенесли ПР, хоча і виявив низький результат при первинному обстеженні, засвідчив їх поступове відновлення впродовж року спостереження. В групах жінок, які перенесли КР, у ранньому та пізньому післяпологовому періоді спостерігалось статистично значуще відставання рольово- 
го функціонування від ГП ( $<0,05)$, очевидно у зв'язку із значними руховими обмеженнями внаслідок наявності рубця черевної порожнини та перебігом післяопераційного періоду. При всіх повторних обстеженнях результати ОГ2 були статистично значуще кращими параметрів ОГ ( $<0,05)$, а з шостого місяця зрівнялись з параметрами ГП.

У ранньому післяпологовому періоді жінки всіх груп відчували біль та дискомфорт (що оцінювали за шкалою Bodily Pain), згладжений у жінок після КР прийомом знеболюючих засобів. В той же час у пізньому післяпологовому періоді вже чітко визначалась різниця між жінками ГП та ОГ2 у порівнянні із ОГ1, в групі яких продовжував зберігатись біль та дискомфорт. Ця різниця поступово згладжувалась; через рік спостереження різниці між групами жінок не визначалось $(\mathrm{p}>0,05)$

При самооцінці жінками загального стану свого здоров'я в даний момент і перспектив відновлення за шкалою General Health жінки ГП показали задовільний вихідний результат та швидкий впевнений приріст вже у пізньому післяпологовому періоді. Жінки після КР значно відставали за вихідним результатом ( $<0,05)$; при першому повторному дослідженні тільки представниці ОГ2наблизились до ГП та далі від них не відставали $(\mathrm{p}<0,05)$, в той час як в ОГ1 відновлення було значно повільнішим.

Результати опитування за шкалою Vitality, засвідчили, що жінки у ранньому післяпологовому періоді почуваються дуже виснаженими, особливо після КР, що характеризувалось статистично значуще гіршим результатом їх відносно стану жінок після природніх пологів $(\mathrm{p}<0,05)$. До кінця пізнього післяпологового періоду стан жінок ГП та ОГ2 почав покращуватися; ця тенденція зберігалася до кінця періоду спостереження. Стан представниць ОГ1 хоча і теж постійно покращувався, проте при жодному контрольному спостереженні не досяг рівнів жінок ГП та ОГ2 (p<0,05).

Результати шкали Social Functioning - соціальне функціонування засвідчили відносно однаково задовільний стан всіх груп жінок після пологів, який з часом покращувався i через рік спостереження досяг високого рівня.

Профіль шкали Role-Emotional у жінок у післяпологовому періоді характеризував стан ризику виникнення післяпологової депресії. Покращення психоемоційного стану у жінок П та ОГ2 відбувалось повільно, але поступально; в той час як у жінок ГП1 цей процес перебігав повільніше, не досягаючи параметрів інших груп.

Самооцінка жінками стану психічного здоров'я за шкалою Mental Health, що характеризує настрій підтвердила наявність пригніченого психоемоційного стану в ранньому післяпологовому періоді. До кінця пізнього післяпологового періоду психоемоційний стан жінок ГП та ОГ 
покращився, втой час як параметри ОГ1 були статистично гіршими $(\mathrm{p}<0,05)$, зрівнюючись тільки на 6 місяці.

Висновки. У ранньому післяпологовому періоді жінки після КР мають гірші показники фізичного функціонування, рольового функціонування, загального здоров'я, життєздатності за SF-36 у порівнянні із жінками після родорозрішення природнім шляхом $(\mathrm{p}<0,05)$. Застосування засобів фізичної терапії дозволило до кінця пізнього пологового періоду жінкам після КР за всіма досліджуваними параметрами досягнути якості життя жінок, які народжували природнім шляхом (p>0,05).

\section{Лiтература:}

1. Chauhan G., Tadi P. Physiology, Postpartum Changes. StatPearls Publishing. 2020 Mar 15.

2. Gauthreaux C., Negron J, Castellanos D., Ward-Peterson M., Castro G., Rodríguez de la Vega P., Acuña J.M. The association between pregnancy intendedness and experiencing symptoms of postpartum depression among new mothers in the United States, 2009 to 2011: A secondary analysis of PRAMS data. Medicine (Baltimore). 2017. 96(6). e5851. doi: 10.1097/MD.0000000000005851.

3. Litwicka K., Greco E. Caesarean scar pregnancy: a review of management options. Curr Opin Obstet Gynecol. 2013. № 25(6). P. 456-461. doi: 10.1097/GCO.0000000000000023.

4. Romano M., Cacciatore A., Giordano R., La Rosa B. Postpartum period: three distinct but continuous phases. J Prenat Med. 2010. № 4(2). P. 22-25. 